\title{
Beijing, Gender and Environment - Challenges for Ecological Sustainability, Development and Justice?
}

\author{
Anke Stock
}

\begin{abstract}
Twenty years ago the Beijing Declaration and Platform for Action was adopted to '.. advance the goals of equality, development and peace for all women everywhere...' (Beijing Declaration, 1995, paragraph 3). ${ }^{1}$ Sustainable Development Goal (SDG) Chapter K (of the Beijing Platform for Action) ${ }^{2}$ on 'women and the environment' laid down three strategic objectives, inter alia, with objective 2 being to 'integrate gender concerns and perspectives in policies and programmes for sustainable development'. This article demonstrates the importance of the implementation of this objective - on the one hand for progress on gender equality, and on the other hand for an ecologically sustainable development.
\end{abstract}

\section{Introduction}

Principle 20 of the Rio Declaration, $1992^{3}$ was the first international statement to highlight that gender inequality is an obstacle for sustainable development by stating: 'Women have a vital role in environmental management and development. Their full participation is therefore essential to achieve sustainable development'. Climate change provides a good example of this assertion: it not only impacts differently on women and men, but their behaviours contribute in different ways to the factors that account for the emergence of climate change (e.g. energy consumption) and men and women also play different roles in climate change mitigation and adaptation (e.g. different use of technologies).

Women and men both face danger from climate change in relation to their livelihoods, their security and their health, but its impact can disproportionately affect women; for instance, there is a higher death rate among women during and after natural disasters (HRC 2009: para. 45). It is the human dimension of the use and management of land and natural and productive resources and the environment that needs closer attention. The different activities men and women undertake in fulfilling their roles and tasks in providing for their livelihoods and that of their families depends on the availability of land and natural and productive resources. ${ }^{4}$ In particular, rural women who spend a lot of time in securing food, water and fuel/ energy for the sustenance, health and wellbeing of their families are in need of land and natural and productive resources, as well as their sound management and an intact environment. Climate change, with its serious ramifications for food, water and other natural resources such as wood and similar energy sources, is a threat to all of these factors. Unequal access to land and natural and productive resources and to decision-making processes can magnify the adverse effects of climate change. Women also play a unique role in the stewardship of natural resources as they hold special knowledge on resource management and the environment, as for example among indigenous women in the management of forests.

The interdependence and interrelatedness between the environment and human rights' as recognised in Resolution A/HRC/RES/25/21 2014 (HRC 2014) leads to the conclusion that environmental deterioration has an impact on all human rights, including women's rights, laid down in paragraph 14 of the Beijing Declaration $(1995)^{5}$ stating that 'women's rights are human rights'.

\subsection{Challenge and opportunity}

The complexity of the links between rights, social dimensions and sustainable development is a challenge that has so far not been addressed adequately in multilateral environmental agreements 
(MEAs). The sustainable development agenda and the development of related legislation, policies and programmes often lack attention to the social dimension, including poverty and a gender-sensitive understanding of human rights (Blomstrom 2013: 60). The Millennium Development Goals (MDGs) faced much criticism due to their compartmentalised approach to issues, such as gender equality ${ }^{6}$ and environmental sustainability, ${ }^{7}$ which are by nature cross-cutting issues. The Agreed Conclusions of the 58th Session of the Commission on the Status of Women (CSW) in 2014 summarised in paragraph 37: 'progress on the MDGs for women and girls has been limited owing to the lack of systematic gender mainstreaming and integration of a gender perspective in the design, implementation, monitoring and evaluation of the Goals' (Economic and Social Council 2014). The strategic objective K. $2^{8}$ of the Beijing Platform for Action (BPfA) has not been adhered to.

Looking from the MDGs and the BPfA to the new sustainable development framework due to be approved in 2015 we need to learn from this failure. If the new post-2015 development framework aims at making a real difference it has to take into consideration a comprehensive approach, relying on a human rights-based approach to sustainable development, including the integration of gender concerns and perspectives.

\section{Experiences from the field: Tajikistan}

Women in Europe for a Common Future's (WECF) project work with grassroots women in Tajikistan provides an insight into the challenges related to the links between ecologically sustainable development and gender equality when looking at the realisation of the right to land and natural and productive resources.

\subsection{Background}

Tajikistan has suffered from political upheaval over the last two decades as well as from a civil war (1992-7). This generally deteriorated the political and socioeconomic situation and had a destabilising effect.

Tajikistan is one of a number of countries which faces gaps within its legal framework and practices in regard to gender equality, in particular within rural communities. Even though equality between men and women has been established by Article $17^{9}$ of the Constitution of the Republic of Tajikistan (1994), traditional gender roles contribute to women having less time for independent financial pursuits. Women tend to lack ownership and control over productive assets, lack professional skills, lack access to finance and access to decision-making powers. ${ }^{10}$ These problems have become even more acute since a substantial part of the male population started to migrate for economic reasons to other countries, such as Russia and Kazakhstan, leaving many women behind to provide for themselves and their dependants on their own.

The Human Development Index value of Tajikistan for 2013 is 0.607 , positioning the country at 133 out of 187 countries (UNDP 2014: 38). Thirty-nine per cent of the population live in multidimensional poverty (UNDP 2014: 183). According to the World Bank, Tajikistan ranks first among European and Central Asian countries in terms of vulnerability to climate change (Shah 2013: 2), in particular due to a low adaptive capacity. Existing problems, such as the feminisation of poverty, are expected to exacerbate Tajikistan's vulnerability. In addition, an expected increase in water shortages due to the disappearance of many small glaciers (Shah 2013: 4) will have severe effects on food security as the country lacks proper irrigation and the use of productive land, since arable land is already scarce (only 7 per cent). WECF's 'Empower Women - Benefit for All' (EWA) programme focusing on the economic empowerment of women within a sustainable development framework shows clearly how these problems hinder women in realising their rights and that women are key for sustainable resource management. ${ }^{11}$

\subsection{Women's right to land and natural and productive resources: legal basis and challenges}

Access to land and natural and productive resources is a prerequisite for the livelihoods of rural women in Tajikistan. Even though Tajikistan has ratified most of the common human rights treaties, implementation is slow. In particular, the right to land and natural and productive resources, with its multiple layers, is far from being recognised. Various reform approaches to alleviate the situation of women regarding their access to land over the last few years have not comprehensively addressed the problem, as gender concerns are not integrated into laws, policies and programmes (Kuvatova 2014: 7).

Ownership of land in Tajikistan lies with the government. Land reforms over the last two decades have concentrated on the rights of individuals or groups on how to use the land and how to transfer these rights. Of particular interest is the Law on Dekhan Farms which provides every Tajik citizen with the right to establish a dekhan farm (family type 
farm) (Pasqual 2012: 10) by applying for a Land Use Certificate. In theory, both women and men are eligible for the land use title; however, in practice women rarely hold such a title.

The main challenge is the distribution of Land Use Certificates, which are often only given to the head of the household - traditionally a man. Other gender stereotypes cultivated by religious or traditional practices hinder women in making use of their right to land. Even though the number of women with access to land (dekhan farms) has risen, women with registered Land Use Certificates still represent less than 10 per cent of the Tajik population (data from 2010; ${ }^{12}$ CEDAW 2012: para 193).

Research by several Tajik non-governmental organisations (NGOs) (Coalition of NGOs of Tajikistan 2012: 53; Kuvatova 2014: 20) undertaken within different projects ${ }^{13}$ has shown that the missing link between the Land Use Certificate and matrimonial property laws is an obstacle. The spouse (male or female) of a formal landholder who received the Land Use Certificate during marriage has no right to the land despite his or her contribution to working on it during the course of the marriage. When a title owner disposes of their land right, for instance while taking on a mortgage, their spouse has no influence whatsoever over this decision. In the case of divorce, the land title cannot be split. In the case of death, a spouse cannot inherit the title. Experience also shows that the same applies when a man migrates to another country: the Land Use Certificate cannot be transferred to the woman who stays behind, often with her children, parents and in-laws.

This situation creates enormous problems for women who stay at home having to provide for their families. Given the peculiarity of land rights in Tajikistan, namely the absence of private ownership, the disposal of the right to use land and the division of property upon the dissolution of a marriage (by death or divorce) have to be addressed adequately in order to secure the right to land, in particular for women. These are gender concerns and perspectives that have been missed out when looking at land law reform.

\section{Conclusion and recommendations}

The right to land and natural and productive resources for women in rural Tajikistan is not a secure right. It cannot be 'owned' in a legal sense and cannot be transferred or inherited.

Furthermore, its realisation depends on many other factors. Due to existing poverty rates and the growing impacts of climate change, in particular on the natural resource of water, women in rural Tajikistan have to fight hard to secure their own and their dependants' livelihoods. Additionally, traditional and religious practices hinder women in enjoying equal rights, and foster patriarchal patterns which discriminate against women and girls. The resurgence of patriarchal attitudes is of particular concern (CEDAW 2007: para 19).

Legal illiteracy and an unawareness of their rights and related issues are also a reason for the difficult situation of women. The Convention on the Elimination of All Forms of Discrimination against Women (CEDAW) Committee has called several times for more state intervention and activities related to awareness raising, trainings and capacity building (CEDAW 2007: paras 33, 34), to avoid gender blindness. Decision-makers have to know the links between gender equality and sustainable development in order to integrate gender into related policies and programmes. This also requires women to participate in decision-making processes. The participation of women and girls in all decisionmaking bodies, in government at local, regional and national levels, and in the executive suites of big companies, is a route to eliminating discriminatory legislation and prejudices, and to raising awareness among decision-makers and the population. Women in Tajikistan hold only 19 per cent of seats in national parliament and not even 6 per cent of ministerial positions (Hausmann, Tyson and Zahidi 2011: 324). At the Jamoat (the lowest level of local representation), less than 20 per cent of seats are held by women. The CEDAW Committee upholds its call for more public participation of rural women and girls in its Concluding Comments of 2007 (CEDAW 2007: para 26) as well as in its Concluding Observations of 2013 (CEDAW 2013: para 30).

These conclusions from the Tajikistan experience lead to the following recommendations:

- At the national level policies and programmes have to be evaluated in terms of their environmental impact and women's equal access to and use of land and natural and productive resources (compare strategic objective K.2.b BPfA).$^{14}$ Climate change with its different levels of impact for women and men has to be taken into particular consideration.

- National strategies for change to eliminate all obstacles to women's full and equal participation in sustainable development, including in adaptation and mitigation measures, and equal access to 
and control over resources have to be developed (compare strategic objective K.2.g BPfA). ${ }^{15}$

- The currently proposed SDGs (Open Working Group on the SDGS 2014) are not sufficiently rights-based. Human rights have to be at the centre of a socially just and ecologically sustainable development and climate change policy. The right to land is of a cross-cutting

\section{Notes}

1 See www.un.org/womenwatch/daw/beijing/ platform/declar.htm.

2 See www.un-documents.net/bpa-4-k.htm.

3 See www.unep.org/Documents.multilingual/ Default.asp?DocumentID =78\&ArticleID $=1163$.

4 Land can be understood to include farmland, wetland, pasture, rangeland, fishery, forest, as well as harvesting and hunting territories. Productive resources encompass property, fisheries, livestock and game.

5 See www.un.org/womenwatch/daw/beijing/ platform/declar.htm.

6 MDG 3: 'Promote Gender Equality and Empower Women'.

7 MDG 7: 'Ensure Environmental Sustainability'.

8 See www.un-documents.net/bpa-4-k.htm.

9 See www.wipo.int/wipolex/en/text.jsp?file_ id $=237282$.

\section{References}

Blomstrom, E. (2013) 'The Case for Gender Equality and Rights in the SDGs', Gender Equality, Women's Rights and Women's Priorities: Recommendations for the Proposed Sustainable Development Goals (SDGs) and the Post-2015 Development Agenda by the Women's Major Group, Women's Major Group: 59-64

Coalition of NGOs of Tajikistan (2012) The Second Shadow Report on the Realization of the Convention on the Elimination of All Forms of Discrimination against Women by Public Organizations of Tajikistan, Dushanbe: Coalition of NGOs of Tajikistan CEDAW (Convention on the Elimination of All Forms of Discrimination against Women) (2013) Concluding Observations on the Fourth and Fifth Periodic Reports. Tajikistan, CEDAW/C/TJK/CO/4-5, New York NY: CEDAW

GEDAW (Convention on the Elimination of All Forms of Discrimination against Women) (2012) Consideration of Reports Submitted by State Parties under Article 18 of the Convention on the Elimination of All Forms of Discrimination against Women, Combined Fourth and Fifth Periodic Report, Tajikistan, CEDAW/C/TJK/4-5, New York NY: GEDAW nature and will only become reality if flanked by other rights and included in different goals, targets and indicators.

Vice versa, the cross-cutting nature of the right to land is crucial to achieving a number of other proposed goals within the post-2015 development framework, for example ending poverty and achieving gender equality.

10 Data available from baseline study of Women in Europe for a Common Future's (WECF) EWA project financed by the Ministry of Foreign Affairs, Netherlands. The project 'Empower Women - Benefit for All' (EWA) is a four-year programme that targets six countries (Afghanistan, Georgia, Kyrgyzstan, South Africa, Tajikistan and Uganda), 100 communities and at least 50,000 women and men (www.wecf.eu/ english/publications/2015/report-tajikistan.php).

11 See endnote 4.

12 See www.wecf.eu/english/publications/2015/ report-tajikistan.php.

13 Inter alia by the EWA project of WECF. 14 See www.un-documents.net/bpa-4-k.htm. 15 See www.un-documents.net/bpa-4-k.htm.

CEDAW (Convention on the Elimination of All Forms of Discrimination against Women) (2007) Concluding Comments of the Committee on the Elimination of Discrimination Against Women. Tajikistan, CEDAW/C/ TJK/CO/3. 2007, New York NY: CEDAW

Economic and Social Council (2014) Challenges and Achievements in the Implementation of the Millennium Development Goals for Women and Girls. Agreed Conclusions, E/CN.6/2014/L.7. 2014, Commission on the Status of Women, FiftyEighth Session, New York NY: Economic and Social Council

Hausmann, R., Tyson, L.D. and Zahidi, S. (2011) The Global Gender Gap Report, Geneva: World Economic Forum

HRC (Human Rights Council) (2014) Human Rights and the Environment, Resolution A/HRC/ RES/25/21 2014, Geneva: Office of the United Nations High Commissioner for Human Rights

HRC (Human Rights Council) (2009) Annual Report of the United Nations High Commissioner for Human Rights and Reports of the Office of the High Commissioner and the Secretary-General, www2.ohchr. org/english/issues/climatechange/docs/A. HRC.10.61_AUV.pdf (accessed 20 May 2015) 
Kuvatova, A. (2014) 'Women and Farming', Women in Europe for a Common Future, Tajikistan: Youth Ecological Center, www.wecf.eu/english/ publications/2014/review-women-farmingtajikistan.php (accessed 20 May 2015)

Open Working Group on the Sustainable Development Goals (2014) Introduction to the Proposal of the Open Working Group for Sustainable Development Goals, Outcome Document, 19 July, http://sustainabledevelopment.un.org/focussdgs. html (accessed 20 May 2015)
Pasqual, L. (2012) Land in the Right Hands: Promoting Women's Rights to Land, Almaty: UN Women

Shah, J. (2013) Tajikistan - Overview of Climate Change, World Bank Group Working Paper, Washington DC: World Bank

UNDP (2014) Human Development Report 2014.

Sustaining Human Progress: Reducing Vulnerabilities and Building Resilience, New York NY: United Nations Development Programme (UNDP) 